\title{
Feasibility of Constructed Wetland Using Coagulation Flocculation Technology in Batik Wastewater Treatment
}

\author{
Erina Rahmadyanti ${ }^{1 *}$, Cyntia Puspa Febriyanti ${ }^{1}$ \\ 1 Department of Civil Engineering, Faculty of Engineering, Universitas Negeri Surabaya, Ketintang, Surabaya, \\ 60231 , Indonesia \\ * Corresponding author's e-mail: erinarahmadyanti@unesa.ac.id
}

\begin{abstract}
The batik industry became a double-edged sword for the development of Indonesia. While it plays a significant role in economy, it also contributes to the environmental pollution, which is mostly caused by the lack of appropriate technology for the wastewater treatment in small industries. This study aims at determining the feasibility in combining the coagulation-flocculation technology using Moringa oleifera seeds powder (MOSP) with horizontal subsurface constructed wetland (HSSFCW) in treating the batik wastewater. The results show that combining $750 \mathrm{mg} / \mathrm{L}$ MOSP in the coagulation flocculation technology with 5 days retention time on HSSFCW optimally removed $89.33 \%$ of the chemical oxygen demand (COD); $98.11 \%$ of total suspended solids (TSS); and $92.05 \%$ of fat, oil, and grease (FOG). Moreover, it increases the $\mathrm{pH}$ conditions up to 7.33. Despite its high removal efficiency, this technology combination is not feasible in the batik wastewater treatment due to inability to meet the standard effluent of the discharged wastewater. Therefore, adding pre-post treatment to this technology implementation is recommended to obtain the standard effluents of wastewater discharged.
\end{abstract}

Keywords: batik industry, coagulation-flocculation, environmental pollution, horizontal sub surface flow constructed wetland, Moringa oleifera seeds powder

\section{INTRODUCTION}

Hand-written batik, a creative art commodity, is one of the oldest cultural products in Indonesia (Zahidi, 2017; Mukimin et al., 2018). Its existence has been recognized worldwide as a cultural heritage by the UNESCO. As one of the oldest cultural heritage, it is spread almost in each region of Indonesia. Hence, there are various motives and patterns grow based on its region specialty. This industry has a significant role in supporting the national economy (Mukimin et al., 2018; Nurhasanah et al., 2015). Batik became a popular product used by both domestic and foreign consumers. The number reached up to $77 \%$ of total Indonesian population and has export value up to USD 340 million in 2014 (Steelyana, 2012; Zahidi, 2017).

Its significant contribution to the national economy is inversely proportional to the environmental damage due to wastewater generation (Mukimin et al., 2018) and dyes which cause the environmental pollution (Raman dan Kanmani, 2016). The dyed water has chemical contents causing various health problems such as jaundice, vomiting and increased heart rate (Khalik et al., 2015). Besides dyes, the batik wastewater has alkali, organic and inorganic salts, acids, heavy metals and other chemicals contents (Raman and Kanmani, 2016). These contents are categorized as pollutants which hardly decompose by microorganisms as well as are difficult to process with the conventional methods (Khalik et al., 2015). Generally, in each production, $90-130 \mathrm{~m}^{3}$ of wastewater is generated per ton that cannot be decomposed and contributes $17-20 \%$ to water pollution (Freitas et al., 2015).

Mostly, batik is a small scale industry run by family. Thus, it has various limitations such as knowledge, technology, and capital, which 
lead to the problems in the wastewater treatment (Mukimin et al., 2018; Birgani et al., 2016). The unorganized and uneven spreading location of this industry in each region creates difficulty in managing the large-scale centralized wastewater treatment (Birgani et al., 2016).

There are several methods involved in treating batik wastewater, such as solar photocatalytic process (Khalik et al., 2015), physical treatment (Rashidi et al., 2013), $\mathrm{TiO}_{2}$ nanoparticles coated on the surface of plastic sheet (Sutisna et al., 2017), bioequalization and electrocatalytic (Mukimin et al., 2018), and nanofiltration membrane (Rashidi et al., 2012).

These technologies have similarities, which include expensive costs, short usage time, and the possibility of stunted bacterial growth (Raman and Kanmani, 2016; Birgani et al., 2016). In turn, the conventional technology in treating the batik wastewater is difficult to implement because of the organic dyes and heavy metals (Raman and Kanmani, 2016; Khalik et al., 2015). Referring to these, sustainable technology that is effective, economical, and environmentally friendly is needed to treat the wastewater (Khalik et al., 2015).

Determining the types of technology based on the characteristics of the wastewater is important. For example, with high turbidity in the batik wastewater, the removal process becomes an important step and it possibly implements the flocculation-coagulation technology (Efendi et al., 2015). Generally, chemical coagulants are used in the conventional coagulation-flocculation process. However, its application has certain disadvantages, including aluminium and iron production, as well as high operational and maintenance costs (Formentini-Dchmitt et al., 2013), high volumes of mud (Dehgani and Alizadeh, 2016), and potential health disruption by triggering some diseases such as Alzheimer's and neurodegenerative (Egbuikwem and Sangodoyin, 2013; Madrona et al., 2017).

These problems encourage conducting many studies in order to find the potential use of the natural coagulants in the coagulation-flocculation process in the wastewater treatment (FormentiniDchmitt et al., 2013; Egbuikwem and Sangodoyin, 2013). The previously researched natural coagulants are starch (potatoes, wheat, corn, and rice starch), sodium alginate, Moringa oleifera, calcium alginate, chitosan, tannin, natural gums and xanthan (Dehgani and Alizadeh, 2016). Out of those, Moringa oleifera (MO) is provably effective as natural coagulant and is almost equivalent to synthetic coagulants (alum) which are widely used in the conventional coagulation flocculation (Madrona et al., 2017; Egbuikwem and Sangodoyin, 2013; Chusan et al., 2014).

The natural coagulants have many advantages, they are cost-effective, capable of treating the wastewater with extreme $\mathrm{pH}$, high levels of insoluble substances (Dehgani and Alizadeh, 2016), lower sludge volumes production (Formentini-Dchmitt et al., 2013), renewable resource, and low toxicity (Charoenlarp and Prabphane, 2015).

In the batik wastewater treatment, the coagulation-flocculation unit cannot be independent but has to be combined with the advanced treatment, such as constructed wetlands (CWs). CWs are one of the environmentally friendly technologies capable of processing various pollutants (Mangangka et al., 2013). CWs are designed and built based on natural processes involving the wetland vegetation (Vymazal, 2014). Moreover, it has lower operational costs than the activated sludge systems and other advanced technologies (ElZein, 2016). CWs can also be used to improve the water quality through the biotic and abiotic processes, provide recreational areas, and remove various dissolved contaminants from agriculture, industry (Vymazal, 2014) and urban sources (Helfield and Diamond, 1997).

CWs have been operated in 38 types in 33 countries that handle a total of 26 types of industrial wastewater. According to Vymazal (2013) CWs have been provably effective in removing BOD (66\%), COD (68-72\%), TSS $(88 \%)$, TN $(52 \%)$, organic N (52\%), sulphate (53-59\%), Cr (40-50\%) and coloring agents $(72-77 \%)$. The success of CWs in treating various types of industrial wastewater becomes the basis for conducting this research, as the batik wastewater contains BOD, COD, dyes, and FOG, it also has high turbidity. Therefore, it is suggested to combine coagulation-flocculation using the natural coagulants of Moringa oleifera seeds (MOS) with CWs. This study generally aimed at determining the feasibility of a coagulation flocculation combination technology using MOS with HSSFCWs to treat the batik wastewater. 


\section{MATERIAL AND METHODS}

\section{Raw wastewater}

The batik wastewater used as raw material in this study was obtained from Namiro Batik which located in Jetis, Sidoarjo. The wastewater was taken from the boiling process. In this process, water evaporation causes higher concentrations of chemicals and high COD values due to the wax addition (Birgani et al., 2016). The analysis of the batik wastewater contents shows high parameters of COD, TSS and FOG, but low pH (Table 1).

These numbers of parameters exceeding the threshold stated in The Regulation of Minister of Environment of The Republic of Indonesia No.5/2014, meaning that it is prohibited from direct discharge into water bodies.

Table 1. Batik wastewater characteristics

\begin{tabular}{|c|c|c|c|}
\hline Parameter & Unit & Value & $\begin{array}{c}\text { Discharge } \\
\text { standards* }^{*}\end{array}$ \\
\hline $\mathrm{pH}$ & - & 4.32 & $6-9$ \\
\hline $\mathrm{COD}$ & $\mathrm{mg} / \mathrm{L}$ & 12,000 & 150 \\
\hline $\mathrm{TSS}$ & $\mathrm{mg} / \mathrm{L}$ & 3,180 & 50 \\
\hline FOG & $\mathrm{mg} / \mathrm{L}$ & 4,970 & 3.0 \\
\hline
\end{tabular}

* The Regulation of Minister of Environment of The Republic of Indonesia No. 5/2014.

\section{Coagulant preparation}

The coagulant used is MOS. MOS is naturally dried, then blended to become MOSP (Moringa oleifera seed powder) (De Paoli and Sperling, 2013). MOSP is heated in the oven at $35^{\circ} \mathrm{C}$ for 5 hours to ensure the dryness (Dehgani and Alizadeh, 2016), then sieved using 60 mesh sieve and 100 mesh (De Paoli and Sperling, 2013). The MOSP is put into $1 \mathrm{~L}$ of distilled water and stirred for 3 minutes at a speed of $120 \mathrm{rpm}$ (Dehgani and Alizadeh, 2016), so $1 \mathrm{~mL}$ coagulant represents $10 \mathrm{mg} / \mathrm{L}$ when added with $1,000 \mathrm{~mL}$ of wastewater (Mghoui, 2018). This solution is filtered to obtain a free coagulant solution from the suspended material. $75 \mathrm{~mL}$ and $150 \mathrm{~mL}$ coagulants are added to get $750 \mathrm{mg} / \mathrm{L}$ and $1500 \mathrm{mg} / \mathrm{L}$. These coagulant solutions are stored with maximum temperature of $20^{\circ} \mathrm{C}$ to avoid $\mathrm{pH}$ and viscosity changes (Dehgani and Alizadeh, 2016).

\section{Coagulation flocculation process}

The coagulation-flocculation process was carried out in the jar test equipment. The batik wastewater in the amount of $500 \mathrm{~mL}$ is poured into a beaker glass and MOSP solutions are added. Subsequently, stirring for 1 minute at $300 \mathrm{rpm}$ was carried out and followed by stirring for 20 minutes at $40 \mathrm{rpm}$. After coagulation-flocculation processes are finished, the solution is left for 30 minutes for the deposition process. The wastewater samples from coagulation-flocculation process form 2 layers, clear in upper layer and turbid in the bottom, as it contains sediment (Vymazal et al., 1998). The processed water is poured into sample bottles and then tested for $\mathrm{pH}, \mathrm{COD}$, TSS, and FOG parameters.

\section{Constructed wetland reactor}

The free space from the planting media to the glass surface in this study was $30-40 \mathrm{~cm}$ wide (Kadlec and Wallace, 2009) with 8 plants $/ \mathrm{m}^{2}$ for the Equisetum hyemale plant density (Formentini et al., 2013; Sutrisno and Wulandari, 2018) and an interval of $25 \mathrm{~cm}$ (Regulation of Minister of Environment of the Republic of Indonesia No.5/2014).

Acclimatization was carried out for 17 days where the first 10 days were watered using the well water and then watered for 7 days using wastewater with gradually increasing concentrations, i.e. 25\%, 50\%, 75\% and 100\% (Wardono et al., 2012). The coagulation-flocculation water was flowed to HSSFCW with retention times of 3 days, 5 days and 7 days. The processed water was then tested for its $\mathrm{pH}, \mathrm{COD}$, TSS, and FOG. A schematic diagram in this study can be seen in Figure 1.

\section{Experimental setup}

The batik wastewater was stored in the $500 \mathrm{~mL}$ basin. The initial treatment is coagulation-flocculation process using $750 \mathrm{mg} / \mathrm{L}$ and $1500 \mathrm{mg} / \mathrm{L}$ of MOSP then to compare the efficiency of both doses in various parameters. The processed water flowed at the rate $11 \mathrm{~mL} / \mathrm{min}$ and hydraulic conductivity of $11 \mathrm{~m} /$ day to HSSFCW. Water drainage was continuously carried out in various detention times before its parameters were measured. The results were compared with the standard quality of wastewater (Al Gheeti et al., 2017).

\section{Analytical method}

COD was measured over 5 days with the incubation temperature of $20^{\circ} \mathrm{C}$ and determined by the dichromate closed reflux and measured using 


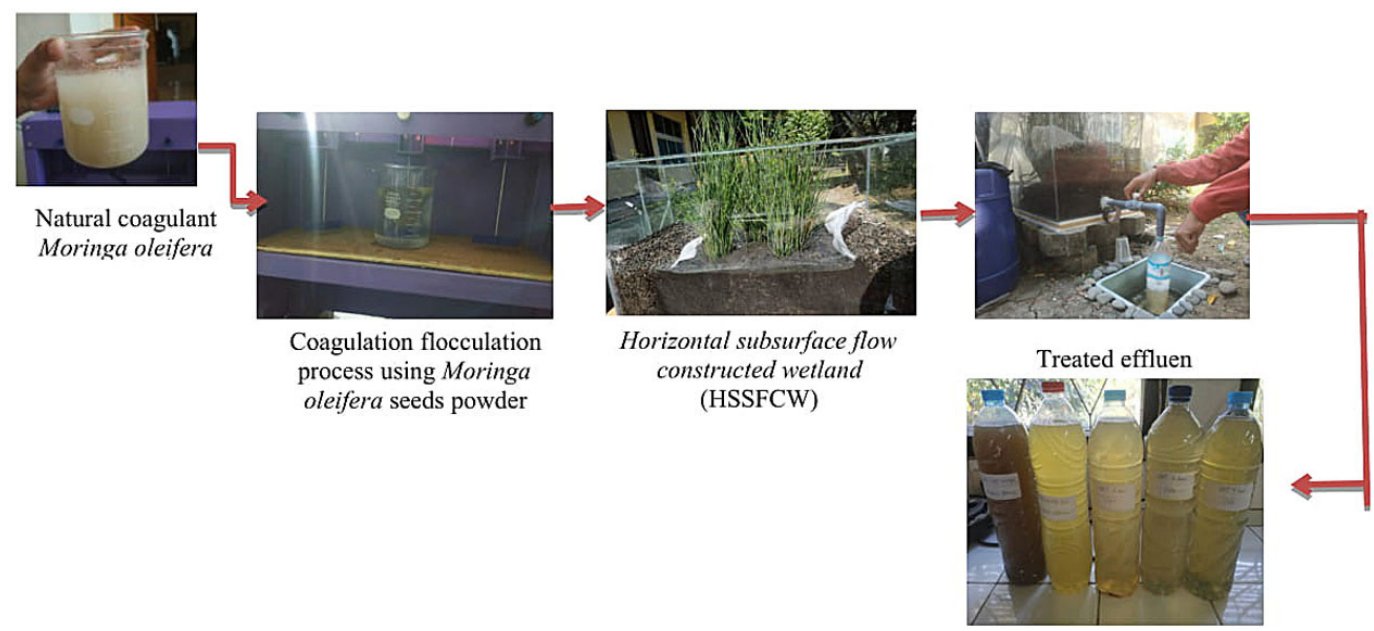

Fig. 1. Schematic experimental diagram

a spectrophotometer. TSS was measured with a gravimetric method where the residue dried into constant weight for at least $1 \mathrm{~h}$ at $103^{\circ} \mathrm{C}$ to $105^{\circ} \mathrm{C}$. The $\mathrm{pH}$ was measured by means of a $\mathrm{pH}$ meter. The FOG concentration was determined using the solvent extraction and separating funnel and compared with the effluent standards (Korkusuz et al., 2004). The measurements were performed on the influent before coagulants were added and on the effluent of HSSFCW.

\section{Statistical analysis}

The data in this study were analyzed using SPSS Statistics v.25. The dependent variables in this study include $\mathrm{pH}, \mathrm{COD}$, TSS, and FOG and were analyzed using the Lavene Test method (Table 2). The variants were homogeneous if the significant values were higher than 0.05 . Table 2 shows that all parameters had a significant value $>0.05$ meaning that all variances were homogeneous). The independent variable in this study was the hydraulic retention time. The variable was tested using a multivariate analysis of variance (MANOVA) test and proven using Pillai's Trace, Wilks Lambda, Hotelling Trace and Roy's Largest Root.

\section{RESULTS AND DISCUSSION}

In order to determine the significant of coagulation-flocculation technology combination using MOSP with HSSFCW, the parameters of wastewater treatment effluents were measured and compared to the influents. The measurements

Table 2. Lavene's test of quality of error variances

\begin{tabular}{|c|c|c|c|c|c|}
\hline & & Levene Statistic & df1 & df2 & Sig. \\
\hline \multirow{4}{*}{$\mathrm{pH}$} & Based on Mean & .400 & 2 & 6 & .687 \\
\hline & Based on Median & .438 & 2 & 6 & .665 \\
\hline & Based on Median and with adjusted df & .438 & 2 & 4.830 & .669 \\
\hline & Based on trimmed mean & .403 & 2 & 6 & .685 \\
\hline \multirow{4}{*}{ COD } & Based on Mean & 2.201 & 2 & 6 & .192 \\
\hline & Based on Median & 2.201 & 2 & 6 & .192 \\
\hline & Based on Median and with adjusted df & 2.201 & 2 & 2.552 & .278 \\
\hline & Based on trimmed mean & 2.201 & 2 & 6 & .192 \\
\hline \multirow{4}{*}{ TSS } & Based on Mean & .857 & 2 & 6 & .471 \\
\hline & Based on Median & .857 & 2 & 6 & .471 \\
\hline & Based on Median and with adjusted df & .857 & 2 & 4.000 & .490 \\
\hline & Based on trimmed mean & .857 & 2 & 6 & .471 \\
\hline \multirow{4}{*}{ FOG } & Based on Mean & 12.121 & 2 & 6 & .008 \\
\hline & Based on Median & 1.101 & 2 & 6 & .391 \\
\hline & Based on Median and with adjusted df & 1.101 & 2 & 2.027 & .474 \\
\hline & Based on trimmed mean & 10.055 & 2 & 6 & .012 \\
\hline
\end{tabular}


were varied based on the MOSP doses $(750 \mathrm{mg} / \mathrm{L}$ and $1500 \mathrm{mg} / \mathrm{L}$ ) and the hydraulic retention times in $\operatorname{HSSFCW}(3,5$, and 7 days) (Table 3).

Dependent variables $(\mathrm{pH}, \mathrm{COD}$, TSS, and FOG) were tested for their effect with the independent variable (hydraulic retention times) using four different multivariate tests, namely Pillai's Trace, Wilks Lambda, Hotelling's Trace, and Roy's Largest Root (Table 4). The results showed that there is a significance of 0.000 with a value $<0.05$ meaning that retention times significantly influence the parameters ( $\mathrm{pH}, \mathrm{COD}, \mathrm{TSS}$, and FOG) in the batik wastewater treatment using coagulation-flocculation combination MOSP with HSSFCW.

The combination of coagulation-flocculation and HSSFCW shows its highest efficiency in removing COD, TSS, and FOG on day 5, reaching $89.33 \%$; $98.11 \%$; and $92.05 \%$, respectively, as well as neutralizing $\mathrm{pH}$ up to 7.33. However, despite its high removal efficiency, this technology is not capable of meeting the standard effluents $(150 \mathrm{mg} / \mathrm{L} \mathrm{COD} ; 50 \mathrm{mg} / \mathrm{L} \mathrm{TSS}$; and $3 \mathrm{mg} / \mathrm{L}$ FOG). Consequently, alternative steps including coagulant variations and processes, media variations, combinations with other treatments are needed in treating the batik wastewater to ensure its standard effluent discharged.

\section{Effect of the technology combination on $\mathrm{pH}$}

The $\mathrm{pH}$ has an important role in the process of coagulation-flocculation. The $\mathrm{pH}$ value which is not optimal impacts the failure of floc formation and the low water quality. There are different optimum values of $\mathrm{pH}$ for each type of coagulant (Hendrawati et al., 2016). Tunggolou and Payus, (2017) found that the efficiency of the coagulation-flocculation process using MOSP has the $\mathrm{pH}$ value less than 6 and greater than 11. This is because the ionized amino acids (found in MOSP) produce the carboxylic ions and protons which attract electrons to form neutral groups and floc (Hendrawati et al., 2016).

The results show that the $\mathrm{pH}$ value increases (tends to be alkaline) during the addition of the MOSP coagulant dose (pH is 4.97 from adding $750 \mathrm{mg} / \mathrm{L} \mathrm{MOSP}$ and 5.14 from adding $1500 \mathrm{mg} / \mathrm{L}$ MOSP. Both results show that the $\mathrm{pH}$ values are less than 6 , becoming optimal for the floc formation process. The forming floc sediments thereby reduce the amount of dissolved solids. Hence, the coagulation-flocculation is effective in the TSS removal. In spite of its optimum condition in floc formation, this treatment is unable to increase $\mathrm{pH}$ as regulated in The Regulation of The Ministry of Environment of Indonesia No. 5/2014 (supposedly 6-9). Therefore, it needs further processing by using HSSFCW.

The $\mathrm{pH}$ increase due to the MOSP addition in the coagulation-flocculation process was also found by Hendrawati, et al. (2016). They found that adding MOSP $100 \mathrm{mg} / \mathrm{L}$ increases $\mathrm{pH}$ from 5.10 to 6.20 . This increase is possibly caused by the cationic water-soluble proteins content found in the skin and seeds of MOSP (where the Alkaline amino acids in the MO protein receive

Table 3. Effluent combinations of coagulation-flocculation and HSSFCW technologies

\begin{tabular}{|c|c|c|c|c|c|c|c|c|}
\hline \multirow{2}{*}{ No } & \multirow{2}{*}{ Parameter } & \multirow{2}{*}{ Unit } & \multirow{2}{*}{ Influent } & \multicolumn{2}{|c|}{ Coagulation-Flocculation } & \multicolumn{3}{|c|}{ Effluent HSSFCW (days) } \\
\cline { 5 - 10 } & & & $750 \mathrm{mg} / \mathrm{L}$ & $1500 \mathrm{mg} / \mathrm{L}$ & 3 & 5 & 7 \\
\hline 1. & $\mathrm{pH}$ & - & 4.55 & 4.97 & 5.14 & 7.20 & 7.33 & 7.52 \\
\hline 2. & $\mathrm{COD}$ & $\mathrm{mg} / \mathrm{L}$ & 12,000 & 4,320 & 4,720 & 1,320 & 1,280 & 1,360 \\
\hline 3. & $\mathrm{TSS}$ & $\mathrm{mg} / \mathrm{L}$ & 3,180 & 690 & 164 & 88 & 60 & 98 \\
\hline 4. & FOG & $\mathrm{mg} / \mathrm{L}$ & 9,740 & 2,632 & 2,876 & 800 & 774 & 824 \\
\hline
\end{tabular}

Table 4. Multivariate test results between retention times of the independent variables

\begin{tabular}{|c|c|c|c|c|c|c|}
\hline & Effect & Value & $\mathrm{F}$ & Hypothesis df & Error df & Sig. \\
\hline \multirow{4}{*}{ Intercept } & Pillai's Trace & 1.000 & 287183.539 & 4.000 & 3.000 & .000 \\
\hline & Wilks' Lambda & .000 & 287183.539 & 4.000 & 3.000 & .000 \\
\hline & Hotelling's Trace & 382911.385 & 287183.539 & 4.000 & 3.000 & .000 \\
\hline & Roy's Largest Root & 382911.385 & 287183.539 & 4.000 & 3.000 & .000 \\
\hline \multirow{4}{*}{ HRT } & Pillai's Trace & 1.979 & 95.184 & 8.000 & 8.000 & .000 \\
\hline & Wilks' Lambda & .000 & 100.058 & 8.000 & 6.000 & .000 \\
\hline & Hotelling's Trace & 373.659 & 93.415 & 8.000 & 4.000 & .000 \\
\hline & Roy's Largest Root & 318.031 & 318.031 & 4.000 & 4.000 & .000 \\
\hline
\end{tabular}


protons from water molecules and release hydroxyl groups in order to keep the water neutral) (Hendrawati et al., 2016; Olanrewaju et al., 2018; Tunggolou and Payus, 2017; Amagloh and Bena$\mathrm{ng}$, 2009). In HSSFCW, the effluent has a $\mathrm{pH}$ increase in line with the hydraulic retention times. On day 3, pH increases from 4.97 to 7.2 ; on day 5 , it increases from 7.20 to 7.33 ; and on day 7 , it increases from 7.33 to 7.52 (Fig. 2).

The $\mathrm{pH}$ value obtained from the HSSFCW effluent ranged from 6.5 to 7.5 (meeting the $\mathrm{pH}$ standards set by The Regulation of The Ministry of Environment of Indonesia No. 5/2014 (supposedly 6-9). The $\mathrm{pH}$ increase occurred along with the length of retention time in HSSFCW and is similarly found in Kadlec and Wallace (2009) who mentioned that in UK, $24 \mathrm{CWs}$ with reed beds have $\mathrm{pH}$ of $7.33 \pm 0.20$ in the period of 1-9 years. In addition, 18 HSSF systems in Norway, Australia, New Zealand and America have showed similar results having pH 7.12 \pm 0.20 in the period of $1-5$ years.

The $\mathrm{pH}$ changes in HSSFCW are caused by microbial activity and the presence of macrophytes (Duran-Dominguez-de-Bazua et al., 2018; Kadlec and Wallace, 2009). Besides, the changes are possibly caused by the interactions between the substrate and its biofilm (Wallace and Knight, 2006; Kadlec and Wallace, 2009). It was proven by previous studies where zeolite or expanded clay (as a medium in the SSF system) caused the media to become alkaline and produce a high $\mathrm{pH}$ in the treated water that is equal to $8.39 \pm 0.18$ (Kadlec and Wallace, 2009).

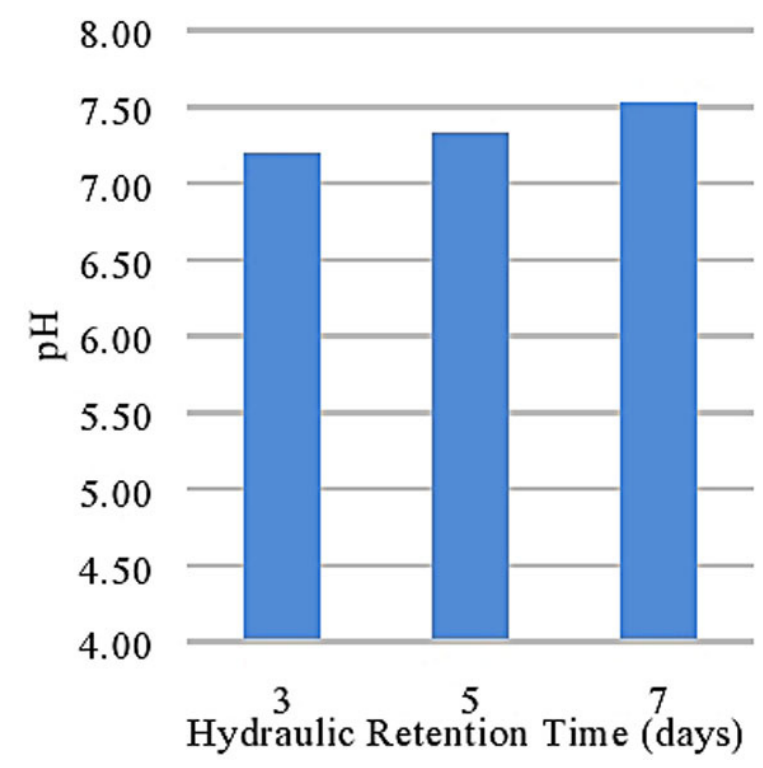

Fig. 2. Effect of technology combination on $\mathrm{pH}$
Moreover, a $\mathrm{pH}$ increase can occur due to high hydroxyl concentrations, biodegradation of organic matter, calcium compounds (Travaini-Lima and Sipauba-Travars, 2012) as well as alkalinity due to the denitrification process (Kadlec and Wallace, 2009).

\section{Effect of the technology combination on COD}

COD indicates the oxygen needed to oxidize the dissolved organic matter in water (Wallace and Knight, 2006). The COD test was carried out to indirectly measure the amount of organic matter in water (Kosseva, 2013) or the decomposed amount of organic pollutants (Li and Liu, 2019). The results of the coagulation-flocculation process showed that using MOSP reduced the COD content. MOSP in the amount of $750 \mathrm{mg} / \mathrm{L}$ is able to remove $\pm 64 \%$ of the COD content in wastewater (from $12,000 \mathrm{mg} / \mathrm{L}$ to $4,320 \mathrm{mg} / \mathrm{L}$ ), while $1500 \mathrm{mg} / \mathrm{L}$ MOSP is able to remove $\pm 60.67 \%$ of the COD content in wastewater (from $12,000 \mathrm{mg} / \mathrm{L}$ to $4,720 \mathrm{mg} / \mathrm{L}$ ). This removal efficiency does not meet the standard COD effluent of discharged wastewater regulated by the government (supposedly $150 \mathrm{mg} / \mathrm{L}$ ).

The COD decrease by adding MOSP in this research is in line with previous studies that found by adding MOSP (in various doses) can reduce the initial COD concentration value of $222 \mathrm{mg} / \mathrm{L}$ into each of the following $10 \mathrm{~g}(77 \mathrm{mg} / \mathrm{L}), 12 \mathrm{~g}$ $(56 \mathrm{mg} / \mathrm{L}), 14 \mathrm{~g}(31 \mathrm{mg} / \mathrm{L}), 16 \mathrm{~g}(29 \mathrm{mg} / \mathrm{L})$, and $18 \mathrm{~g}(9 \mathrm{mg} / \mathrm{L})$ (Qomariyah et al., 2017). In addition, Al-Gheeti et al. (2017) found that adding $90 \mathrm{mg} / \mathrm{L}$ MOSP has $42.73 \%$ of COD removal efficiency (Sari et al., 2016; Billore et al., 2009).

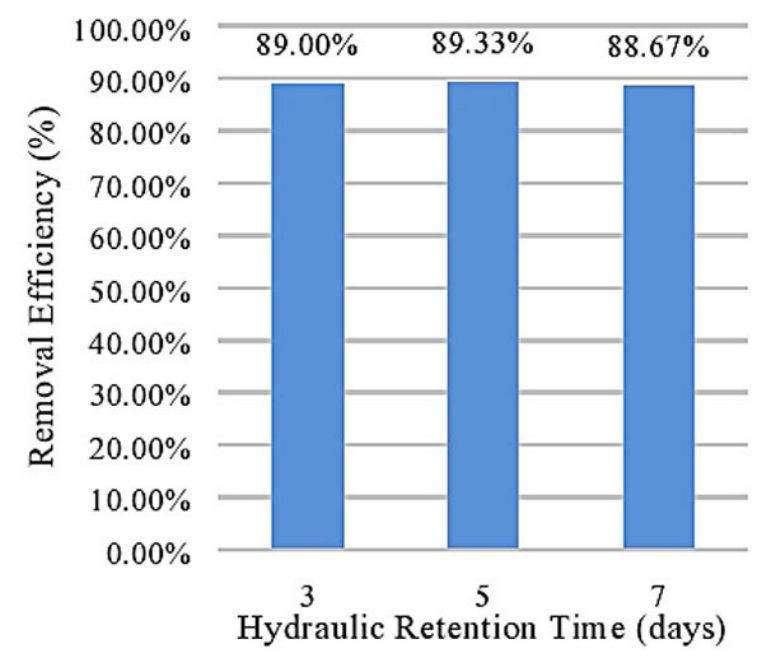

Fig. 3. Effect of combination technology on COD 
MOSP has the removal efficiency at higher doses or exceeding the optimum dose over the COD removal content in the treated water. The decreasing MOSP effectiveness on the COD parameters is due to its high organic content of $15,000 \mathrm{mg} / \mathrm{L}$ (for MO seeds with shells) and $9,630 \mathrm{mg} / \mathrm{L}$ (for MO seeds without shells) (Satterfield, 2005; Wardono et al., 2017).

This organic content caused the coagulation-flocculation process of the oil content in MOSP not fully removed (Vymazal, 2010). The remaining organic matter caused an increase in the COD content at higher coagulant doses or exceeded the optimum dose (Wardono et al., 2017; El Enshasy et al., 2018). The COD increase was due to the exceeding of optimum MOSP dose (which also occurred in the previous studies where $3 \%$ of MOSP coagulant in leachate treatment increased COD from $520.5 \pm 0.71 \mathrm{mg} / \mathrm{L}$ to $987.0 \pm 2.83 \mathrm{mg} / \mathrm{L}$ and in the Baluk river water treatment increased the COD removal from $132.0 \pm 2.83 \mathrm{mg} / \mathrm{L}$ to $164.0 \pm 2.83 \mathrm{mg} / \mathrm{L}$ ) (Vymazal, 2010); adding $5 \%$ of MOSP coagulant increased the COD removal from $281 \mathrm{mg} / \mathrm{L}$ to $650 \mathrm{mg} / \mathrm{L}$ (Wardono et al., 2017); and increased the COD removal from $3712.5 \mathrm{mg} / \mathrm{L}$ to $4900 \mathrm{mg} / \mathrm{L}$ for adding $30 \mathrm{~g} / \mathrm{L}, 6682.5 \mathrm{mg} / \mathrm{L}$ for adding $40 \mathrm{~g} / \mathrm{L}$, and $7720.5 \mathrm{mg} / \mathrm{L}$ for adding a dose of $50 \mathrm{~g} / \mathrm{L}(\mathrm{El}$ Enshasy et al., 2018).

The COD removal also occurs when batik wastewater enters HSSFCW. In the initial stage (on day 3), COD reduced from $1,320 \mathrm{mg} / \mathrm{L}$ to $690 \mathrm{mg} / \mathrm{L}$ or had $69.44 \%$ removal efficiency. Then, on day 5, it increased into $70.37 \%$; however, on day 7 , it decreased to $68.52 \%$ (see Fig. 3). The decrease in the COD removal efficiency is caused by the decomposition of the organic matter done by aerobic microbes and aerobes in HSSFCW (De Paoli \& Sperling, 2013; Saeed \& Sun, 2012) as well as sedimentation (Qin and Chen, 2016; Vymazal and Kröpfelová, 2009).

The removal process occurred through two mechanisms, namely the simplification of polymers into monomers such as amino acids, fatty acids, and monosaccharaides (Megonikal et al., 2004). Furthermore, it is also due to the ammonification process that produced fatty acids such as acetic acid, butyric and lactic, alcohol as well as $\mathrm{CO}_{2}$ and $\mathrm{H}_{2}$ gases (Vymazal and Kröpfelová, 2009; Qin and Chen, 2016) by nitrifying bacteria (Vymazal et al., 1998).

\section{Effect of the technology combination on TSS}

In the TSS removal, using $750 \mathrm{mg} / \mathrm{L}$ and $1500 \mathrm{mg} / \mathrm{L}$ MOSP as able to reduce TSS from $3,180 \mathrm{mg} / \mathrm{L}$ to $690 \mathrm{mg} / \mathrm{L}$ (having the removal efficiency of $78.3 \%$ ) and from $3,180 \mathrm{mg} / \mathrm{L}$ to $164 \mathrm{mg} / \mathrm{L}$ (having the removal efficiency of 94.84\%). However, despite its high removal efficiency, adding $750 \mathrm{mg} / \mathrm{L}$ and $1500 \mathrm{mg} / \mathrm{L}$ MOSP in this research still did not meet the standard effluents of discharged wastewater regulated by The Regulation of The Ministry of Environment of Indonesia No. 5/2014 (supposedly $50 \mathrm{mg} / \mathrm{L}$ ).

The previous studies found a high TSS efficiency of $99.2 \%$ by using MOSP in the coagulation-flocculation process of wastewater treatment (Qomariyah et al., 2017) (De Paoli \& Sperling, 2013). Another research found that adding $40 \mathrm{mg} / \mathrm{L}$ and $70 \mathrm{mg} / \mathrm{L}$ MOSP had the TSS removal efficiency of $67.7 \%$ and $70.9 \%$, respectively (Chusan et al., 2014; Madrona et al., 2017). The decrease in TSS also occurred from $1248 \mathrm{mg} / \mathrm{L}$ to $270 \mathrm{mg} / \mathrm{L}$ by adding $30 \mathrm{~g} / \mathrm{L}$ MOSP and from $204 \mathrm{mg} / \mathrm{L}$ to $156 \mathrm{mg} / \mathrm{L}$ by adding dose $50 \mathrm{~g} / \mathrm{L}$ MOSP (El Enshasy et al., 2018). The decrease in TSS is caused by the role of basic polypeptides in MO which has a molecular weight of 6000-16000 Daltons (De Paoli and Sperling, 2013). Basic positively charged polypeptides conduct electrostatic interactions by sticking to the surface of the negatively charged particles, such as clay, bacteria, and dust (Chusan et al., 2014; Satterfield, 2005; Qomariyah et al., 2017)(De Paoli and Sperling, 2013). At this stage, two mechanisms occurred simultaneously (adsorption and neutralization of particles mechanism as well as unstable adsorption and binding between particles mechanism) (Madrona et al., 2017; Charoenlarp and Prabphane, 2015), and the suspended particles move form lumps into larger molecules before sedimenting and separating from contaminants (De Paoli and Sperling, 2013).

Unlike the effect of MOSP on the COD removal, adding MOSP with a higher dose results in higher TSS removal efficiency (Madrona et al., 2017). It is caused by two mechanisms during the removal process (adsorption and neutralization of particles and unstable adsorption and binding between particles) (Chusan et al., 2014) as the higher the dose of coagulant, the higher the mechanism process. In addition, $\mathrm{MO}$ - as the main coagulant - is more effective in water with high turbidity (Egbuikwem and Sangodoyin, 
2013; Ndabigengesere and Narasiah, 2010) because water with low turbidity contains lower colloidal particles, so the contact between particles in the system becomes low (Egbuikwem and Sangodoyin, 2013). In this research, the $1500 \mathrm{mg} / \mathrm{L}$ of MOSP has higher TSS removal efficiency but it has lower removal efficiency in terms of COD and FOG.

The follow-up process in using HSSCW is carried out because the TSS content resulted from the coagulant-flocculation process using MOSP (with $750 \mathrm{mg} / \mathrm{L}$ and $1500 \mathrm{mg} / \mathrm{L}$ ) did not meet the standard TSS effluent of discharged wastewater regulated by the government. By then, $87.25 \%$ of removal efficiency was obtained on day 3 (from $690 \mathrm{mg} / \mathrm{L}$ to $88 \mathrm{mg} / \mathrm{L}$ ) and $91.30 \%$ of removal efficiency on day 5 (from $690 \mathrm{mg} / \mathrm{L}$ to $60 \mathrm{mg} / \mathrm{L}$ ) (Fig. 4). The increases of the TSS removal efficiency on day 5 were due to sedimentation of smaller particles which cannot settle on day 3 at the inlet. In the process of sedimentation, the largest and heaviest particles settle on the inlet or inlet section. Smaller and denser particles require additional hydraulic retention time. However, on day 7 , the TSS removal efficiency decreased into $85.80 \%$ (at $80 \mathrm{mg} / \mathrm{L}$ ) due to the occurrence of particle re-suspension (Wallace and Knight, 2006).

The TSS removal process in HSSFCW is due to the deposition process caused by the interception of suspended solids because of the reduced speed of water flow through wetland media (Wallace and Knight, 2006; Kadlec and Wallace, 2009; Andreo-Martínez et al., 2016; Vymazal et al., 1998; Wallace and Knight, 2006; Weerakoon et al., 2018), aggregation or flocculation (Wallace \& Knight, 2006), and filtration (AndreoMartínez et al., 2016; Kadlec and Wallace, 2009;

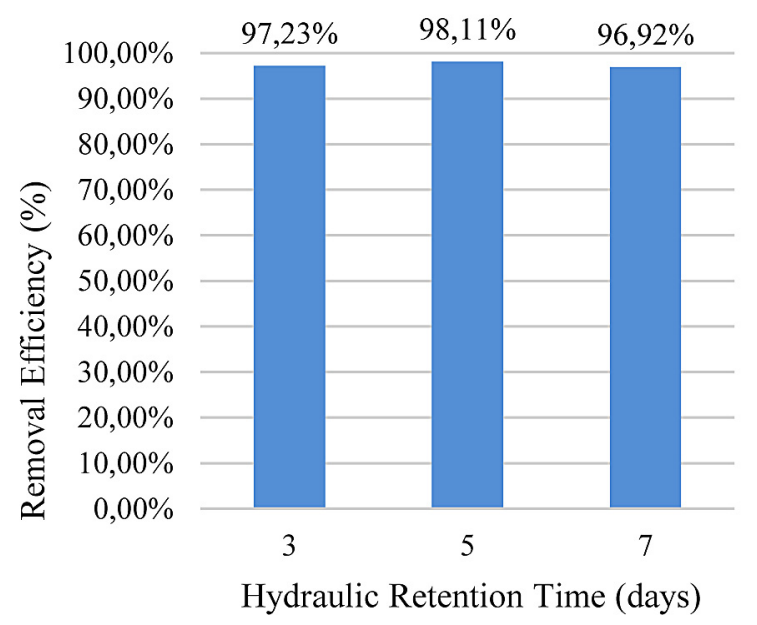

Fig. 4. Effect of combination technology on TSS
Vymazal et al, 1998; Wallace and Knight, 2006; Weerakoon et al., 2018). In fine-grained media, the interception process occurs randomly either at the micro scale (Brownian motion) or macro scale (bioturbation) which makes it easy for the particles to settle (Kadlec and Wallace, 2009; Vymazal et al., 1998).

\section{Effect of the technology combination on FOG}

FOG is a part of lipids consisting of fatty acids, triacylglycerol, and fat-soluble hydrocarbons (Husain et al., 2014). The FOG content in the batik wastewater was detected at $9,740 \mathrm{mg} / \mathrm{L}$. Adding $750 \mathrm{mg} / \mathrm{L}$ of MOSP in the coagulation flocculation process enabled able to reduce the FOG to $2.632 \mathrm{mg} / \mathrm{L}$ (having the removal efficiency of $78.07 \%$ ), yet adding $1500 \mathrm{mg} / \mathrm{L}$ lowers the removal efficiency by $76.03 \%$ (reduce to $2.876 \mathrm{mg} / \mathrm{L}$ ). This value still did not meet the threshold set by the government (supposedly $3 \mathrm{mg} / \mathrm{L}$ ).

The FOG removal by MOSP is not in line with the previous research which says that the MO oil extraction is not needed in the coagulation-flocculation process or sedimentation (Billore et al., 2009). The decrease in the removal efficiency is along with the MOSP doses addition. This is due to the large amount of fatty oil in the extract water of MOSP (by 29.5\%) (Mghaoui, 2018). This amount is added to the wastewater content which is by $37 \%$. Accordingly, it means during the coagulation flocculation process the oil content in the MOSP was not completely removed (Vymazal, 2010), by then the higher dose of MO seeds, the higher FOG content remains in the treated water. Therefore, if $\mathrm{MO}$ is not extracted in advance, the right dose in treating fat oil in the

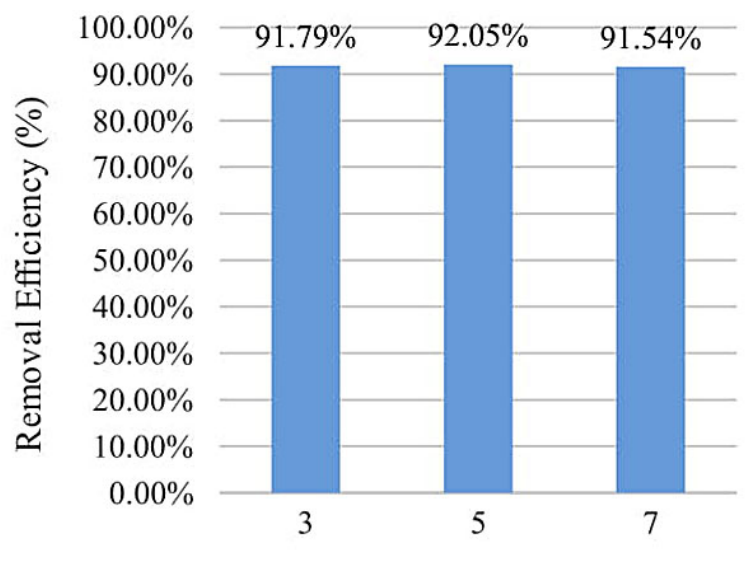

Hydraulic Retention Time (days)

Fig. 5. Effect of combination technology on FOG 
batik wastewater is $750 \mathrm{mg} / \mathrm{L}$, but for more optimal results, the extraction is needed in order to remove the MOSP oil content. The following process was done through the HSSFCW at retention time of 3 days resulting in $69.60 \%$ of removal efficiency. Subsequently, an increase in removal efficiency to $70.59 \%$ occurred at detention time of 5 days (Fig. 5). However, this removal efficiency decreased to $68.69 \%$ on day 7 retention time.

The similar FOG decrease also occurred in the previous research where the microbial Bacillus cereus and Pseudomonas aeruginosa in organic fertilizers and modified strains were able to remove $98.25 \%$ of FOG in HSSFCW with plants and $16-44 \%$ of FOG in HSSFCW without plants. HSSFCW was able to process FOG due to the existence of several types of microfits which are provably effective in degrading contaminants (Mustafa, 2013). Lipids, fatty acids, triacylglycerol, and dissolved hydrocarbons contained in fatty oils can be decomposed by the microorganisms that live in HSSFCW aerobically. In addition, the decrease in FOG was possibly caused by the solids filtered on the media where sticking on the cavities between media and forms biofilms (Vymazal and Kröpfelová, 2009).

\section{CONCLUSIONS}

Combining the coagulation-flocculation technology using MOSP with HSSFCW for the batik wastewater treatment is not effective in removing parameters (COD, TSS, and FOG) to meet the standard effluents of discharged wastewater regulated by The Regulation of The Ministry of Environment of Indonesia No. 5/2014, despite its high removal efficiency. However, this technology is capable of increasing the $\mathrm{pH}$ value to neutral condition (up to 7.33).

\section{REFERENCES}

1. Al-Gheeti, A., Radin, M.R.M.S., Ahmed A., Nurulainee, N.R., Mas Rahayu, J., and Amir H.M. 2017. Efficiency of Moringa oleifera seeds for treatment of laundry wastewater. MATEC Web of Conference, 103.

2. Amagloh, K.F., and Benang, A. 2009. Effectiveness of Moringa oleifera seed as coagulant for water purification. African Journal of Agricultural Research, 119-123.

3. Andreo, P.M., N. García-Martínez and Amela, L.
2016. Domestic wastewater using a depuration horizontal subsurface flow constructed wetland and theoretical optimization: A case study under dry Mediterranean climate. Water, 8, 434, 1-18.

4. Billore, S.K., Prashant and Sharm, J.K. 2009. Treatment performance of artificial floating reed beds in an experimental mesocosm to improve the water quality of river Kshipra. IWA Publishing.

5. Birgani, P.M., Ranjbar, N., Abdullah, R.C., Wong, K.T., Lee, G., Ibrahim, S., Park, C., Yppn, Y., and Jang, M. 2016. An efficient and economical treatment for batik textile wastewater containing high levels of silicate and organic pollutants using a sequential process of acidification, magnesium oxide, and palm shell-based activated carbon application. Journal of Environmental Management, 184, 229-239.

6. Charoenlarp, K., and Prabphane, P. 2015. Ecofriendly decolorization of textile wastewater using natural coagulants. Researchgate, 45-55.

7. Chusan, T., Makky, E.A., Ali, E.N. and Al Matar, M. 2014. The use of Moringa oliefera seed as a natural coagulant for wastewater treatment and heavy metals removal. Jokull Journal, 64(8), 188-200.

8. Dchmitt Formentini, D.M., Dias Alves, A.C., Veit, M.T., Bergamasco, R., Salcedo Vieira, A.M., and Fagundes-Klen, M.R. 2013. Ultrafiltration combined with coagulation/flocculation/sedimentation using Moringa oliefera as coagulant to treat dairy wastewater industry. Springer Science, Business media, 224, 1682, 1-10.

9. Dehghani, M., and Alizadeh, M.H. 2016. The effects of the natural coagulant Moringa oliefera and alum in wastewater treatment at the banda abbas oil refinery. Environmental Health Engineering and Management Journal, 3(4), 225-230.

10. De Paoli, A.C., and Sperling, M.V. 2013. Evaluation of clogging in planted and unplanted horizontal subsurface flow constructed wetland: accumulation and hydraulic conductivity reduction. IWA Publishing, 1345-1352.

11. Duran-Dominguez-de-Bazua, M.D.C., WavarroFrometa, A.E., and Bayona, J.M. 2018. Artificial or constructed wetlands: A suitable technology for sustainable water management. CRC press.

12. Efendi, H., Sari, R.D., and Hasibuan, S. 2015. Moringa oleifera as coagulant for batik effluent treatment. International association for impact assessment (IAIA 15) Conference, 1-6.

13. Egbuikwem, P.N., and Sangodoyin, A.Y. 2013. Coagulation efficacy of Moringa oleifera seed exract compared to alum for removal of turbidity and E.coli in three diffferent water sources. European International Journal of Science and Technology, 2(7), 13-19.

14. El Enshasy, H.A., Hanapi, S.Z., Abdel Galil, S.A., Abd Malek, R., and Pareek, A. 2018. Mycoremediation : potential of fungal ligninolytic declourization 
enzyms, in mycroremediation and environmental sustainability. Fungal Biology, 1, 240 pages.

15. ElZein, Z., Abdou, A., and ElGawad I.A. 2016. Constructed wetlands as a sustainable wastewater treatment method in communities. Procedia Environmental Sciences, 34, 605-617.

16. Freitas, T., Oliveira, V., de Souza, M., Geraldino, H., Almedia, V., Favaro, S., and Garcia, J. 2015. Optimization of coagulation-flocculation process for treatment of industrial textile wastewater using okra (A. esculents) mucilage as natural coagulant. Industrial Crops and Products, 538-544.

17. Hendrawati, I.R., Yuliastri, Nurhasni, E., Rohaeti, H., Effendi and Darusman, L.K. 2016. The use of Moringa oleifera seed powder as coagulant to improve the quality of wastewater and ground water. Earth and Environmental Science, 1-10.

18. Helfield, J.M., and Diamond, M.L. 1997. Use of constructed wetland for urban stream restoration: A critical analysis. Environmental Management, 21(3), 329-341.

19. Husain, I.A.F., Alkhatib, M.F., Jammi, M.S., Mirghani, M.E.S., Zainudin, Z.B., and Hoda, A. 2014. Problems, control, and treatment of fat, oil, and grease (FOG): A review. Journal of Oleo Science, 63(8), 747-752.

20. Kadlec, R.H., and Wallace, S.D. 2009. Treatment wetlands. Taylor \& Francis Group, 2nd Ed., Amerika, CRC Press, 965.

21. Khalik, W.F., Ho, L.N., Ong, S.A., Wong, Y.S., Yusoff, N.A. and Ridwan, F. 2015. Decolorization and mineralization of batik wastewater through solar photocatalytic process. Sains Malaysiana, 4(44), 607-612.

22. Korkusuz, E.A., Beklioglu, M., Demirer, G.N., 2005. Comparison of the treatment performances of blast furnace slag-based and gravel-based vertical flow wetlands operated identically for domestic wastewater treatment in Turkey. Ecological Engineering, 24, 187-200.

23. Kosseva, M.R. 2013. Sources, characterization, and composition of food industry wastes. Food Industry Wastes, pp. 37-60.

24. Li, D., and Liu, S. 2019. Detection of river water quality-chapter 7. Water Quality Monitoring and Management, 21-220.

25. Madrona, G.S., Scapim, M.S.R., Tono, L.A., Reis, M.H.M., Paraiso, C.M. and Bergamasco, R. 2017. Use of Moringa oliefera in combined coagulaltionfiltration process for water treatment. The Italian Association of Chemical Engineering, 57, 1195-1200.

26. Mangangka, I.I., Egodawatta, P., Parker, N.T., Gardner and Goonetilleke, A. 2013. Water Science \& Technology, 68(10), 2195-2201.

27. Megonikal, J.P., Hines, M.E., Visscher, P.T. 2004.
Anaerobic metabolism: linkage to trace gases and aerobic processes. In : Schlesinger WH, editor. Biogeochemistry. Oxford, U.K. Elsevier-Pergamon, 317-424.

28. Mghaoui, M.E. 2018. Design of a trout for constructed wetland wastewater treatment. Al Akhawayn University, Morroco.

29. Mukimin, A., Vistanty, H., Zen, N., Purwanto, A., and Wicaksono, K.A. 2018. Performance of bioequalization-electrocatalytic integrated method for pollutants removal of hand-drawn batik wastewater. Journal of Water Process Engineering, 77-83.

30. Mustafa, A. 2013. Constructed wetland for wastewater treatment and reuse: A case Study of developing country. International Journal of Environmental Science and Development, 4, 1, 20-24.

31. Ndabigengesere, A., and Narasiah, K.S. 2010. Use of Moringa oleifera seeds as a primary coagulant in wastewater treatment. Environmental Technology, 19(8), 789-800.

32. Nurhasanah, S., Sudrajat, R.L., Srinovita, Y., and Trisnawati, E. 2016. Optimization of batik fashion based cultural heritage as a competitive advantage in the ASEAN Economic Anticipating Commodity (AEC) in 2015. Proceedings of the 29th International Conference IRES, 29, 18-23.

33. Olanrewaju, O.O., Jegede, O.J., and Adeoye, I.A. 2018. Comparisson of the coagulation efficiency of mo (linnaeus) on wastewater at lower and higher concentration levels. International Journal of Engineering Science and Application, 2(3), 98-105.

34. Qin, R., and Chen, H. 2016. The procession of constructed wetland removal mechanism of pollutant. International Conference on Mechanical Materials and Manufacturing Engineering, 568-570.

35. Qomariyah, S., Sobriyah, Koosdaryani and Muttaqien, A.Y. 2017. Lahan basah buatan sebagai pengolahan limbah cair dan penyedia air non-konsumsi. Jurnal Riset Rekayasa Sipil Universitas Sebelas Maret, 1(1), 25-32.

36. Raman, C.D., and Kanmani, S. 2016. Textile dye degradation using nano zero valent iron: A review. Journal of Environmental Management, 177, 341-355.

37. Rashidi, H.R., Nik Sulaiman, N.M., Hashim, N.A., and Che Has, C.R. 2013. Synthetic batik wastewater pretreatment progress by using physical treatment. Advanced Materials Research, 627, 394-398.

38. Rashidi, H.R., Nik Sulaiman, N.M. and Hashim, N.A. 2012. Batik industry synthetic wastewater treatment using nanofiltration membrane. Procedia Engineering, 142-144.

39. Regulation of the Minister of Environment of the Republic of Indonesia Number 5/2014 on Wastewater Quality Standard. 
40. Saeed, T., and Sun, G. 2012. A review on nitrogen and organic removal mechanism in subsurface flow constructed wetlands: dependency on environmental parameters, operating, and supporting media. Journal of Environmental Management, 112, 429-448.

41. Sari R.A., Pinem, J.A., and David, S.2016. Utilization of Moringa seed (Moringa oleifera) as a coagulant in brackish water treatment become water use coagulation ultrafiltration process," Journal FTEKNIK, 3, 1, 1-7.

42. Satterfield, Z. 2005. Jar testing. National Environmental Service Center, 5(1), 1-4.

43. Steelyana, E. 2012. Batik, a beautiful cultural heritage that preserve culture and support economic development in Indonesia. BINUS Business Review, 3(1), 16-130.

44. Sutisna, E., Wibowo, M., Rokhmat, D., Rahman, Y., Khairurrijal, R., and Abdullah, M. 2017. Batik wastewater using $\mathrm{TiO} 2$ nanoparticles coated on the surface of plastic sheet. Engineering Physics International Conference, EPIC 2016, 170, 78-83.

45. Sutrisno and Wulandari, D. 2018. Multivariate analysis of variance (Manova) for enriching educational research. Axiom, 9(1), 37-53.

46. Tunggolou, J., and Payus, C. 2017. Moringa oleifera as coagulant used in water purification process for consumption. Earth Science Pakistan, 1(2), 1-3.

47. Travaini-Lima, F., and Sipauba-Travars L.H. 2012. Efficiency of constructed wetlands for wastewater treatment. Acta Limnoloogica Brasiliensia, 24(3), 255-265.

48. Vymazal, J., Brix, H., Copper, P.F., Haberl, R., Perfler, R., and Laber, J. 1998. Removal mechanisms and types of constructed wetlands. 17-66.

49. Vymazal, J., and Kröpfelová, L. 2009. Removal of organics in constructed wetlands with horizontal sub-surface flow: A review. Science of the Total Environmental, 407, 3911-3922.

50. Vymazal, J. 2010. Constructed wetlands for wastewater treatment. Water, 2, 530-549.

51. Vymazal, J. 2013. The use of hybrid constructed wetlands for wastewater treatment with special attention to nitrogen removal: A review of recent development. Water Research, 47, 4795-4811.

52. Vymazal, J. 2014. Constructed wetlands for treatment of industrial wastewater: A review. Ecological Engineering, 73, 724-751.

53. Wallace, D., and Knight, R. L. 2006. Small-scale constructed wetland treatment systems : Feasibility, design, and $\mathrm{O} \& \mathrm{M}$ Requirements. London: IWA Publishing, p. 275.

54. Wardono, H.R.I., Abdullah, S., and Budiono, Z. 2017. Scouring-rush horsetail's (Equisetum hyemale) capability to reduce detergent, cod and phosphat (PO4) levels of laundry wastewater in Purwokerto in 2016. International Conference on Applied Science and Health. ICASH-A27, 160-167.

55. Weerakoon, G.M.P.R., Jinadasa, K.B.S.N., Herath, G.B.B., Mowjood, M.I.M., and Ng, W.J. 2018. Applicability of constructed wetlands for water quality improvement in a tea estate catchment: The Pwsellawa case study. Water, 10, 332, 2-12.

56. Zahidi, M.S. 2017. Batik as indonesian public diplomacy in ASEAN Economic Community (AEC). International Journal of International Relations, Media and Mass Communication Studies, 3(2), 1-9. 